\title{
Prevalence and Antibiotic Susceptibility of Salmonella Strains Isolated from Viscera of Quail (Coturnix coturnix japonica) Breeds in Bingerville Area, Côte d'Ivoire
}

\author{
Aya Carole Bonny, \\ Riviere Assandi, \\ Tago Germain Karou,
}

Laboratory of Biotechnologies, Department of Research and Training Unit of Biosciences, Félix Houphouët-Boigny University (Cocody, Abidjan),

Côte d'Ivoire

Doi:10.19044/esj.2019.v15n24p132ＵRL:http://dx.doi.org/10.19044/esj.2019.v15n24p132

\begin{abstract}
The control of food products contamination by Salmonella has become essential for the consumer to ensure the safety of these foods. Poultry meat and eggs play an important role as infection risk factors related to Salmonella strains resistant to antibiotics. Quail breeding, which is becoming to be appreciated by the Ivoirian population after chicken meat, may contain Salmonella pathogenic strains. Thus, a preliminary survey in two areas of high quail production (ANNA and SANTAI) in the city of Bingerville (Côte d'Ivoire), allowed collecting 60 viscera of quail for microbiological analysis. The microbiological analysis revealed 25 strains of Salmonella isolated from 11 viscera, resulting in a prevalence rate of $18.33 \%$. These strains also showed high resistance to Tetracycline $(100 \%)$, a relatively average resistance to Nalidixic acid (24\%) and low resistance to Ampicillin (8\%), Ticarcillin (8 $\%)$ and Cotrimoxazole ( $8 \%$ ). The presence of antibiotic-resistant strains of Salmonella in quail viscera could constitute a public health problem.
\end{abstract}

Keywords: Quail, Salmonella, Antibiotic resistance, Food safety, Bingerville (Côte d'Ivoire)

\section{Introduction}

The poor microbiological quality of food is responsible for foodborne illnesses and causes considerable damage in the world. This makes Food Security a major challenge for governments, consumers and producers. The pathogenic microorganisms commonly found in foods are 
Campylobacter, Salmonella, Escherichia coli, Staphylococcus and Clostridium. The genus Salmonella is the main cause of foodborne gastroenteritis in humans (Gordana et al., 2012). Indeed, Salmonella infections, also known as salmonellosis, account for 22 millions of disease cases per year in the world. This proportion makes infections due to Salmonella a threat to public health (Goburn et al., 2007).

The emergence of Salmonella resistant to antibiotics has become an epidemiological problem. The development of antibiotic-resistant against the bacteria is also another public health problem in the world. Salmonella antibiotic-resistance continues to increase as a result of excessive use of antibiotics in animal husbandry (WHO, 2010).

In recent decades, Salmonella resistant to antibiotics have been recognized as a threat to public health in most developing countries. Thus the need to control Salmonella contamination of food products is necessary.

Antibiotic resistant Salmonella strains have been isolated from chickens in several countries (Bonny et al., 2011; Bonny et al., 2014; Karou et al., 2013; Ouattara et al., 2013), turkeys (Karraouan et al., 2010) and ducks (Adzitey et al., 2011). Quail meat is becoming more and more appreciated by consumers because it contains a good proportion of protein just like the other products, an appreciable amount of trace elements, and a varied fat content. In addition, this meat is accessible to all budgets.

This study was undertaken in order to establish a database on antibiotic resistance of Salmonella strains isolated in poultry in Côte d'Ivoire, by evaluating the level of antibiotic of Salmonella isolated from farmed quail in Côte d'Ivoire.

\section{Material and methods}

Sampling

This study was conducted in two (2) villages (ANNA and SANTAI) in the area of Bingerville, in Abidjan District (Figure 1). A non-random sampling method allowed to retain two (2) quail farms with more than 2,000 quail heads, which supplied poultry and eggs to restorators and poultry markets. In each farm, Thirty (30) quail (Photography 1) were bought, slaughtered and the viscera (Photography 2) was collected. At each site, 10 viscera were collected per week. Each viscera was placed in a sterile stomacher bag and placed in a cooler containing cold accumulator and, then transported to the laboratory for analyses. 


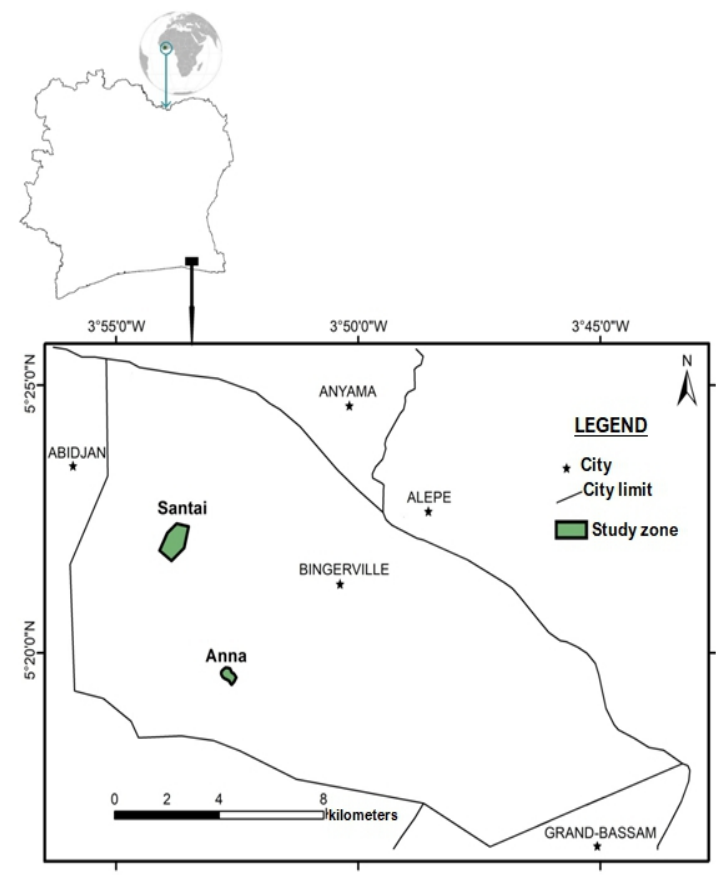

Figure 1: Location of the study areas

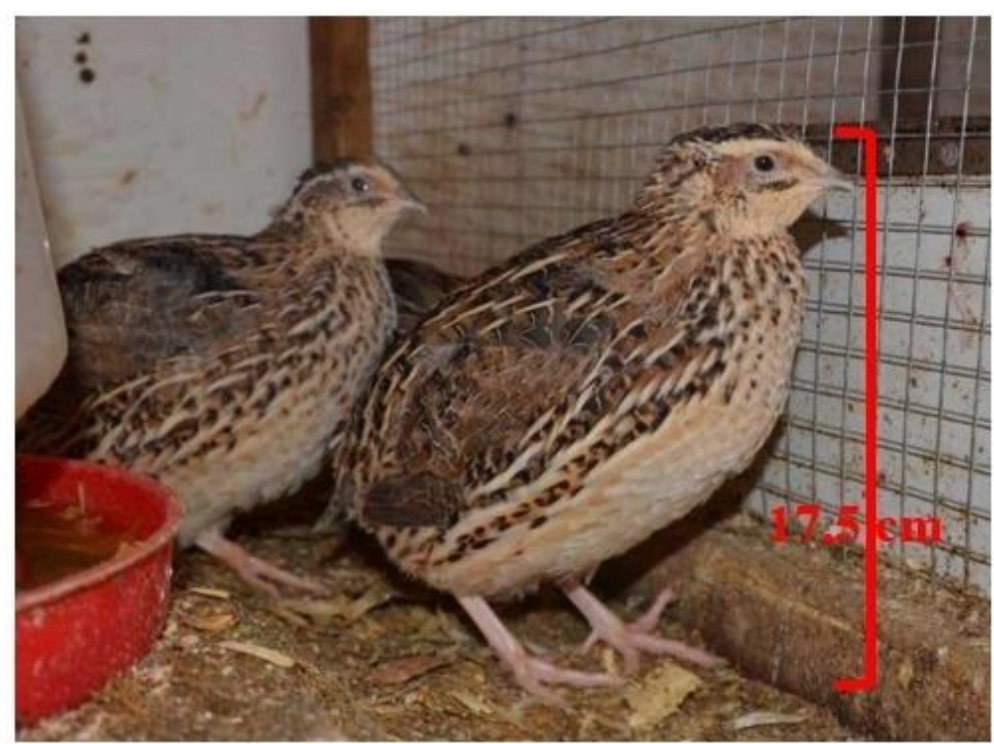

Photography 1: Quail breeds (Coturnix coturnix japonica) 


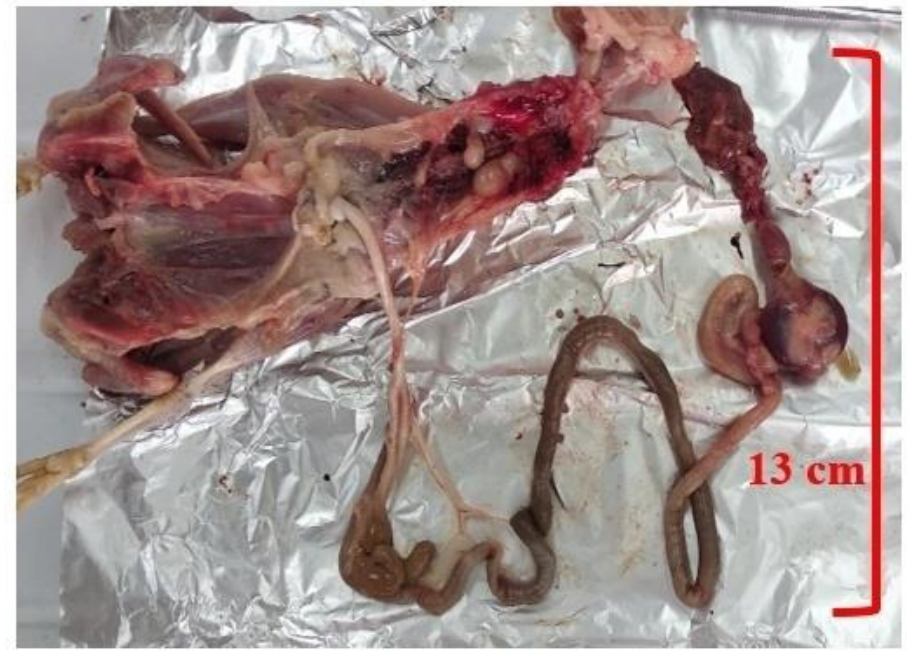

Photography 2: Quail viscera

\section{Bacteriology test for the isolation of Salmonella spp.}

All strains were isolated according to the protocol described by standard ISO 6579 (ISO-6579-1, 2017) in 4 steps. The primary enriching stage often (10) grams of crushed quail viscera in $90 \mathrm{~mL}$ of BPW (Buffered Peptone Water) (BIORAD, France); a selective enrichment stage of $0.1 \mathrm{~mL}$ and $1 \mathrm{~mL}$ of the pre-enriched broth in respectively $10 \mathrm{~mL}$ of Rappaport Vassilliadis broth (BIO-RAD) and Müller-Kauffman Tetrationate broth (BIO-RAD, France); the isolation of presumptive strains onto two selective agar plates namely Hecktoen and XLD (Xylose-Lysine-Desoxycholate) media (BIORAD, France).

Salmonella presomptive colonies obtained were tested for catalase and oxidase test and Gram control. Finally, the isolates were identified on the reduced rack of LEMINOR constituted of four culture media (Kligler-Hajna/ Mannitol-Mobility/Urea indol/Simmons Citrate) to determine its biochemical characteristics.

\section{Analysis of suspicious strains of Salmonella by the MALDITOF (matrix assisted laser desorption ionisation time-of-flight)}

For the confirmation of the genus Salmonella spp, $1 \mu 1$ of each colony of Salmonella presumptive strains was removed and then deposited on target wells of a slide (DS) (BIOMERIEUX). Subsequently, $1 \mu \mathrm{L}$ of matrix CHCA ( $\alpha$-cyano-4hydroxycinnamic acid) was added. After drying at room temperature, the blade was placed on a blade holder (BIOMERIEUX), and the whole was introduced into the Vitek MS (BIOMERIEUX) for analysis. Escherichia coli ATCC 8739 reference strain contained in one of the wells of the DS blade (BIOMERIEUX) is used as a standard. 


\section{Antibiotic susceptibility testing}

After confirming biochemical tests, Salmonella strains were tested for their resistance to some antibiotic used in both veterinary and human medicine. These tests were carried out by diffusion in an agar medium, according to CLSI standard (Clinical Laboratory Standard Institute) on Müller-Hinton agar (BioRad, France) (CLSI, 2005). The antibiotic discs (BioRad, France) used to demonstrate the resistance profile of isolated Salmonella strains were: amoxicillin (AMX, 25 $\mu \mathrm{g}$ ), Cefalotin (CF, $30 \mu \mathrm{g}$ ), Cefoxitin (FOX, $30 \mu \mathrm{g}$ ), Cefotaxime (CTX, $30 \mu \mathrm{g}$ ), Ticarcillin (TIC, $75 \mu \mathrm{g}$ ),

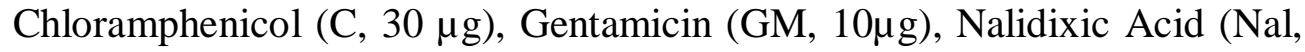
$10 \mu \mathrm{g}$ ), Ciprofloxacin (Cip, $10 \mu \mathrm{g}$ ), Cotrimoxazole (SXT, 10/20 $\mu \mathrm{g}$ ), Tetracycline (TE, $10 \mu \mathrm{g})$, Tobramycin (TM, $10 \mu \mathrm{g})$. The reference strains of Salmonella named ATCC 14028, was used to validate the antibiogram test.

\section{Results}

\section{Bacteriology tests for the isolation of Salmonella spp.}

Microbiological analysis of the gastrointestinal tract of the quail marketed in the town of Bingerville allowed to determine their microbiological status compared to Salmonella. Thus, of the 60 viscera of quails analyzed, 11 viscera were contaminated. Of these 11 viscera contaminated, 25 presumptive strains of Salmonella were isolated, a rate of $18.33 \%$ and an isolation rate of $41.66 \%$. The 25 presumptive isolates of Salmonella isolated had the following biochemical characteristics: Gram negative $\left(\mathbf{G r a m}^{-}\right)$; presence of catalase $\left(\right.$Catalase $\left.{ }^{+}\right)$; absence of an oxidase (Oxidase $^{-}$); Aero-Anaerobic Optional (AAF); ferment glucose $\left(\mathbf{G l u}^{+}\right)$; do not ferment lactose (lactose $\left.{ }^{-}\right)$; ferment mannitol $\left(\right.$mannitol $\left.^{+}\right)$; production of hydrogen sulphide $\left(\mathbf{H}_{2} \mathbf{S}^{+}\right)$; gas production $\left(\right.$gas $\left.^{+}\right)$; use of citrate as a carbon source $\left(\right.$ citrate $\left.^{+}\right)$; lacking urease $\left(\right.$urea $\left.^{-}\right)$; lacking tryptophanase (indole ${ }^{-}$); peritrich mobility $\left(\mathbf{m o b i l i t y}^{+}\right)$.

\section{Analysis of suspicious strains of Salmonella by the MALDITOF (matrix assisted laser desorption ionisation time-of-flight)}

Confirmation of the genus of these presumptive strains was carried out on Vitek MS of MALDITOF. This method made it possible to obtain an identification percentage of $99.9 \%$ of these bacterial strains. So, all the bacterial strains belong to the genus Salmonella spp.

\section{Antibiotic susceptibility testing}

The 25 strains of Salmonella spp. were analyzed for their resistance to the 12 antibiotics. This study allowed to classified, according to the CLSI standards in: resistant or sensitive. Salmonella strains isolated from quail viscera showed low resistance to Amoxicillin, Ticarcillin and Cotrimoxazole 
(8\%), a relatively average resistance to Nalidixic Acid (24\%). However, all isolated strains showed resistance to tetracycline (100\%). For Cephalotin, Cefoxitin, Cefotaxime, Gentamycin, Tobramycin, Chloramphenicol, and Ciprofoxacin, no resistance was observed (0\%) (Figure 2).

The overall profile of antibiotic resistance of Salmonella spp. isolated from quail viscera is presented in table 1. Analysis of the resistance profiles revealed two levels of antibiotic resistance (Table 2). The first level of resistance refers to 15 isolated strains with only one type of profile (TE), involving only the Cyclin family. The second level of resistance concerns the resistance of isolated strains (10 strains) to two (2) families with different combinations including Cyclins, Quinolones, Sulfamides and $\beta$-lactams. The different resistance profiles observed at this level are: SXT-TE (2 strains); TE-NA (6 strains); TE-TIC-AMX (2 strains). However no strain of Salmonella isolated from quail viscera in this study was found to be multidrugresistant. 
Table 1: Global Antibiotic Resistance (ATB) Profiles of Salmonella spp. Strains Isolated from Quail Viscera

\begin{tabular}{|c|c|c|c|c|c|c|c|c|c|c|c|c|c|}
\hline Strains & AMX & TIC & CEF & FOX & CTX & GEN & TM & $\mathrm{CHL}$ & $\mathrm{SXT}$ & CIP & $\mathrm{AN}$ & $\mathrm{TE}$ & Resistance Profiles \\
\hline S7H1C & $\mathrm{S}$ & $\mathrm{S}$ & $\mathrm{S}$ & $\mathrm{S}$ & $\mathrm{S}$ & $\mathrm{S}$ & $\mathrm{S}$ & $\mathrm{S}$ & $\mathbf{R}$ & $\mathrm{S}$ & $\mathrm{S}$ & $\mathbf{R}$ & SXT-TE \\
\hline S7H1A & $\mathrm{S}$ & $\mathrm{S}$ & $\mathrm{S}$ & $\mathrm{S}$ & $\mathrm{S}$ & $\mathrm{S}$ & S & $\mathrm{S}$ & $\mathrm{S}$ & $\mathrm{S}$ & $\mathrm{S}$ & $\mathbf{R}$ & $\mathrm{TE}$ \\
\hline S7X1C & $\mathrm{S}$ & $\mathrm{S}$ & $\mathrm{S}$ & $\mathrm{S}$ & $\mathrm{S}$ & $\mathrm{S}$ & S & $\mathrm{S}$ & $\mathrm{S}$ & $\mathrm{S}$ & $\mathbf{R}$ & $\mathbf{R}$ & TE-NA \\
\hline S7H1B & $\mathrm{S}$ & $\mathrm{S}$ & $\mathrm{S}$ & $\mathrm{S}$ & $\mathrm{S}$ & $\mathrm{S}$ & S & $\mathrm{S}$ & $\mathrm{S}$ & $\mathrm{S}$ & $\mathrm{S}$ & $\mathbf{R}$ & $\mathrm{TE}$ \\
\hline S7X1A & $\mathrm{S}$ & $\mathrm{S}$ & $\mathrm{S}$ & $\mathrm{S}$ & $\mathrm{S}$ & $\mathrm{S}$ & S & $\mathrm{S}$ & $\mathrm{S}$ & $\mathrm{S}$ & $\mathrm{S}$ & $\mathbf{R}$ & TE \\
\hline S7X1B & $\mathrm{S}$ & $\mathrm{S}$ & $\mathrm{S}$ & $\mathrm{S}$ & $\mathrm{S}$ & $\mathrm{S}$ & S & $\mathrm{S}$ & $\mathrm{S}$ & $\mathrm{S}$ & $\mathrm{S}$ & $\mathbf{R}$ & TE \\
\hline S4H1A & $\mathrm{S}$ & $\mathrm{S}$ & $\mathrm{S}$ & $\mathrm{S}$ & $\mathrm{S}$ & $\mathrm{S}$ & S & $\mathrm{S}$ & $\mathbf{R}$ & $\mathrm{S}$ & $\mathrm{S}$ & $\mathbf{R}$ & SXT-TE \\
\hline $\mathrm{S} 17 \mathrm{H} 2 \mathrm{C}$ & $\mathrm{S}$ & $\mathrm{S}$ & $\mathrm{S}$ & $\mathrm{S}$ & $\mathrm{S}$ & $\mathrm{S}$ & S & $\mathrm{S}$ & $\mathrm{S}$ & $\mathrm{S}$ & $\mathrm{S}$ & $\mathbf{R}$ & TE \\
\hline S17H2B & $\mathrm{S}$ & $\mathrm{S}$ & $\mathrm{S}$ & $\mathrm{S}$ & $\mathrm{S}$ & $\mathrm{S}$ & S & $\mathrm{S}$ & $\mathrm{S}$ & $\mathrm{S}$ & $\mathrm{S}$ & $\mathbf{R}$ & TE \\
\hline S22H3D & $\mathrm{S}$ & $\mathrm{S}$ & $\mathrm{S}$ & $\mathrm{S}$ & $\mathrm{S}$ & $\mathrm{S}$ & S & $\mathrm{S}$ & $\mathrm{S}$ & $\mathrm{S}$ & $\mathrm{S}$ & $\mathbf{R}$ & $\mathrm{TE}$ \\
\hline $\mathrm{S} 22 \mathrm{H} 3 \mathrm{~A}$ & $\mathrm{~S}$ & $\mathrm{~S}$ & $\mathrm{~S}$ & $\mathrm{~S}$ & $\mathrm{~S}$ & $\mathrm{~S}$ & S & $\mathrm{S}$ & $\mathrm{S}$ & $\mathrm{S}$ & $\mathrm{S}$ & $\mathbf{R}$ & TE \\
\hline $\mathrm{S} 22 \mathrm{H} 3 \mathrm{C}$ & $\mathrm{S}$ & $\mathrm{S}$ & $\mathrm{S}$ & $\mathrm{S}$ & $\mathrm{S}$ & $\mathrm{S}$ & S & $\mathrm{S}$ & $\mathrm{S}$ & $\mathrm{S}$ & $\mathrm{S}$ & $\mathbf{R}$ & TE \\
\hline S23H3A & $\mathrm{S}$ & $\mathrm{S}$ & $\mathrm{S}$ & $\mathrm{S}$ & $\mathrm{S}$ & $\mathrm{S}$ & $S$ & $\mathrm{~S}$ & $\mathrm{~S}$ & $\mathrm{~S}$ & $\mathrm{~S}$ & $\mathbf{R}$ & $\mathrm{TE}$ \\
\hline $\mathrm{S} 26 \mathrm{H} 3 \mathrm{~B}$ & $\mathrm{~S}$ & $\mathrm{~S}$ & $\mathrm{~S}$ & $\mathrm{~S}$ & $\mathrm{~S}$ & $\mathrm{~S}$ & S & $\mathrm{S}$ & $\mathrm{S}$ & $\mathrm{S}$ & $\mathrm{S}$ & $\mathbf{R}$ & TE \\
\hline $\mathrm{S} 26 \mathrm{H} 3 \mathrm{~A}$ & $\mathbf{R}$ & $\mathbf{R}$ & $\mathrm{S}$ & $\mathrm{S}$ & $\mathrm{S}$ & $\mathrm{S}$ & S & $\mathrm{S}$ & $\mathrm{S}$ & $\mathrm{S}$ & $\mathrm{S}$ & $\mathbf{R}$ & TE-TIC-AMX \\
\hline $\mathrm{S} 26 \mathrm{H} 3 \mathrm{C}$ & $\mathrm{S}$ & $\mathrm{S}$ & $\mathrm{S}$ & $\mathrm{S}$ & $\mathrm{S}$ & $\mathrm{S}$ & S & $\mathrm{S}$ & $\mathrm{S}$ & $\mathrm{S}$ & $\mathrm{S}$ & $\mathbf{R}$ & $\mathrm{TE}$ \\
\hline S29H3C & $\mathrm{S}$ & $\mathrm{S}$ & $\mathrm{S}$ & $\mathrm{S}$ & $\mathrm{S}$ & $\mathrm{S}$ & S & $\mathrm{S}$ & $\mathrm{S}$ & $\mathrm{S}$ & $\mathrm{S}$ & $\mathbf{R}$ & TE \\
\hline S29H3B & $\mathrm{S}$ & $\mathrm{S}$ & $\mathrm{S}$ & $\mathrm{S}$ & $\mathrm{S}$ & $\mathrm{S}$ & S & $\mathrm{S}$ & $\mathrm{S}$ & $\mathrm{S}$ & $\mathrm{S}$ & $\mathbf{R}$ & TE \\
\hline $\mathrm{S} 30 \mathrm{H} 3 \mathrm{C}$ & $\mathbf{R}$ & $\mathbf{R}$ & $\mathrm{S}$ & $\mathrm{S}$ & $\mathrm{S}$ & $\mathrm{S}$ & S & $\mathrm{S}$ & $\mathrm{S}$ & $\mathrm{S}$ & $\mathrm{S}$ & $\mathbf{R}$ & TE-TIC-AMX \\
\hline A7H1B & $\mathrm{S}$ & $\mathrm{S}$ & $\mathrm{S}$ & $\mathrm{S}$ & $\mathrm{S}$ & $\mathrm{S}$ & S & $\mathrm{S}$ & $\mathrm{S}$ & $\mathrm{S}$ & $\mathbf{R}$ & $\mathbf{R}$ & TE-NA \\
\hline A9H1A & $\mathrm{S}$ & $\mathrm{S}$ & $\mathrm{S}$ & $\mathrm{S}$ & $\mathrm{S}$ & $\mathrm{S}$ & S & $\mathrm{S}$ & $\mathrm{S}$ & $\mathrm{S}$ & $\mathrm{S}$ & $\mathbf{R}$ & TE \\
\hline A9S1B & $\mathrm{S}$ & $\mathrm{S}$ & $\mathrm{S}$ & $\mathrm{S}$ & $\mathrm{S}$ & $\mathrm{S}$ & S & $\mathrm{S}$ & $\mathrm{S}$ & $\mathrm{S}$ & $\mathbf{R}$ & $\mathbf{R}$ & TE-NA \\
\hline $\mathrm{A} 11 \mathrm{H} 2 \mathrm{C}$ & $\mathrm{S}$ & $\mathrm{S}$ & $\mathrm{S}$ & $\mathrm{S}$ & $\mathrm{S}$ & $\mathrm{S}$ & S & $\mathrm{S}$ & $\mathrm{S}$ & $\mathrm{S}$ & $\mathbf{R}$ & $\mathbf{R}$ & TE-NA \\
\hline A11S2A & $\mathrm{S}$ & $\mathrm{S}$ & $\mathrm{S}$ & $\mathrm{S}$ & $\mathrm{S}$ & $\mathrm{S}$ & S & $\mathrm{S}$ & $\mathrm{S}$ & $\mathrm{S}$ & $\mathbf{R}$ & $\mathbf{R}$ & TE-NA \\
\hline $\mathrm{A} 11 \mathrm{H} 2 \mathrm{~B}$ & $\mathrm{~S}$ & $\mathrm{~S}$ & $\mathrm{~S}$ & $\mathrm{~S}$ & $\mathrm{~S}$ & $\mathrm{~S}$ & $\mathrm{~S}$ & $\mathrm{~S}$ & $\mathrm{~S}$ & $\mathrm{~S}$ & $\mathbf{R}$ & $\mathbf{R}$ & TE-NA \\
\hline
\end{tabular}

AMX:Amoxicillin; CF: Cefalotin; FOX: Cefoxitin; CTX: Cefotaxim; TIC: Ticarcillin; C: Chloramphenicol; GM: Gentamicyn; Nal: Nalidixic Acide; Cip: Ciprofloxacin; SXT:Cotrimoxazole; TE:Tetracycline; TM:Tobramycin. 
Table 2: Levels of resistance to antibiotic families of Salmonella spp strains isolated from Quail Viscera

\begin{tabular}{llllll}
\hline Levels & $\begin{array}{l}\text { Number of } \\
\text { antibiotic }\end{array}$ & Resistance Profile & $\begin{array}{l}\text { Number } \\
\text { of strains }\end{array}$ & Familly involved \\
\hline Level 1 & 1 & TE & 15 & Cycline & \\
\hline & 2 & SXT-TE & 2 & & \\
Level 2 & 3 & TE-NA & 6 & $\begin{array}{l}\text { Sulfamide, } \\
\text { Quinolone, } \\
\text { (2)-lactamins }\end{array}$ & Cyclin, \\
\hline
\end{tabular}

AMX: Amoxicillin; NA: Nalidixic Acid; TE : Tectracyclin; TIC: Ticarcillin; SXT: Cotrimoxazole.

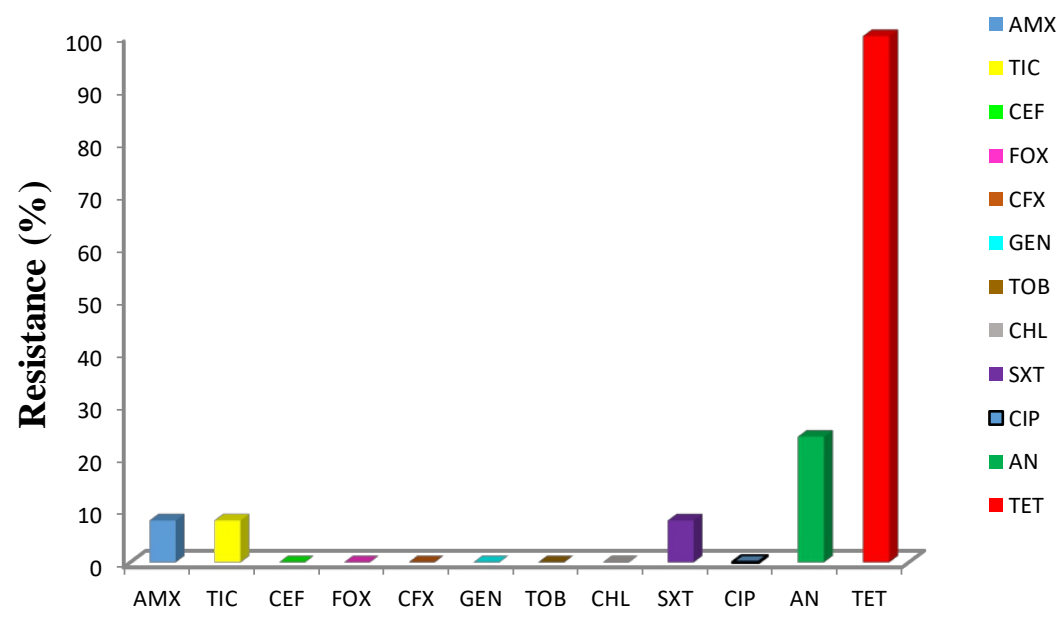

Antibiotic molecules

Figure 2 : Levels of resistance to antibiotic of Salmonella spp strains isolated from Quail Viscera

\section{Discussion}

The presence of Salmonella strains in quail viscera, revealed a contamination of these viscera with a carriage rate estimated at $18.33 \%$. That confirms the hypothesis that Salmonella strains are present in poultry. Indeed, previous studies on other types of poultry also revealed the presence of Salmonella strains in the raw gizzard of broilers in Turkey (18.6\%) (Carli et $a l ., 2001)$, at the level of raw turkey minced meat in Morocco (20.31\%) (Karraouan et al., 2010), Chicken carcasses in Tchad (65.85\%) (Abba et al., 2017), in the intestines of chicken at the stage of slaughter in Côte d'Ivoire (56 \%) (Traoré, 2003) and on raw chicken gizzard samples (61.87 \%) in Côte d'ivoire (Bonny, 2015), the weavers faeces in Cameroon (78.46 \%) (Piebeng et al., 2014), on avian products (chicken carcass, turkey carcass) in the Czech 
Republic (16.6 \%) (Myskovâ and Karpîskovâ, 2017), on the chicken livers (35 $\%)$, gut (30\%), lung (10\%) and kidney (15\%) in Pakistan (Rafiullah et al., 2018). Also, Carli et al. (2001) reports that the rate of contamination at the level of poultry farms by Salmonella was estimated at $41.3 \%$ in Turkey, while in Sénégal, Cardinale et al. (2004) reported an estimated carry rate of $28.6 \%$.

The presence of Salmonella in the quail viscera could facilitate crosscontamination during laughter, in case of defective hygienic practices during the production of poultry products (Bonny et al., 2018). In view of these results, it is worth noting that the exact origin of Salmonella contamination of poultry is still unknow, but it is thought to be related to their diet, drinking water, environmental conditions of cleaning and maintenance.

The Salmonella strains isolated were found to belong to the genus Salmonella by using the technical of MALDI-TOF (99.99\%). They were also tested for their susceptibility to 12 antibiotics commonly used in veterinary and human medicine.

The results show that all the 25 isolates of Salmonella exhibit total resistance to tetracycline (100\% TE). The high level of resistance obtained at the tetracycline level in this study is similar to the rate obtained in chicken samples in Iran by (Fallah et al., 2013). A high level of tetracycline (73\%) was also obtained by Bonny et al. (2014), on the raw chicken gizzards in Côte d'Ivoire and by Diouf (2006) on broiler meat in Senegal. Abba et al. (2017), others scientists in Tchad, obtained an average rate of $51.22 \%$ on chicken meat. The high rate of resistance observed to Tetracycline in this study could explain its use in poultry farming, more specifically in the quail breeding. The investigation conducted during this study, showed that quail farmers use: antibiotics as prophylactic agentsto prevent the appearance of probable pathologies; for the treatment of disease cases and as a food additive or as growth factor for all types of poultry. These commonly used antibiotics belong to the cyclin family, which could explain the strong resistance to tetracycline observed in this work. However, a non negligible resistance to nalidixic acid (24\%) was also observed. This is confirmed in the work carried out on Salmonella strains by Bonny et al. (2014) on the raw chicken gizzard in Côte d'Ivoire (35.76 \%), by Bouzidi (2013) on chickens in Algeria (63.15\%), by El Allaoui et al. (2017) on turkey in Morocco (37.1\%) and by Myskovâ and Karpîskovâ (2017) on poultry meat in the Czech Republic. All these observations could explain the probable use of Quinolones (nalidixic acid) during antibiotic therapy in poultry farming. The analysis of the different profiles observed in this study indicates that antibiotic families such as Quinolones, Sulfamides, Cyclins and $\beta$-lactams are the most involved in the antibiotic resistance of Salmonella strains isolated from quail viscerain Côte d'Ivoire. Indeed, according to Chaslus-Dancla (2003) the unreasonable use of 
antibiotics generally, in intensive breeding leads to the appearance and selection of resistant bacteria. Also, the appearance of resistant profil involving these families of antibiotics would be the direct consequence of their uncontrolled use in the Ivorian poultry sector (Ouattara et al., 2013).

Thus, the presence of Salmonella strains, resistant to antibiotics, isolated in quail viscera could be a problem of safety for this food.

\section{Conclusion}

This study on the prevalence of Salmonella strains in quail viscera revealed a high level of resistance to antibiotics such as tetracycline (100\%). Therefore, such an observation requires close to actors in the poultry sector, a control of their use to ensure the safety of these foods linked to human consumption.

\section{References:}

1. Abba, H., Somda, M. K., Antipas, B. B., Barro, N. and Traore, A. S. (2017). Prévalence et susceptibilité aux antibiotiques des souches de Salmonella spp. non typhiques isolées de la viande de poulets au Tchad. International Journalof Biology, Chemistry and Science, 11(1), 108-117.

2. Adzitey, F., Rusul, G. and Huda, N. (2011). Prevalence and antibiotic résistance of Salmonella sérovars in ducks: duck rearing and processing environments in Penang, Malaysia. Food Research International, 45, 947-952.

3. Bonny, A. C. (2015). Profils phénotypique et moléculaire de l'antibiorésistance de souches de salmonellaisolées de gésiers crus de poulets (gallus gallus domesticus) vendus dans le district d'Abidjan (Côte d'ivoire). Thèse de Doctorat de l'Université Félix Houphouët Boigny, Abidjan, Côte d'ivoire. 165.

4. Bonny, A. C., Karou, T. G., Atobla, K., Bohoua, L. G. and Niamkey, L. S. (2011). Portage de Salmonella au niveau du gésier cru de poulets exposés a la vente à Abidjan, Côte d'ivoire. Journal of Applied Bioscences, 47, 3230-3234.

5. Bonny, A. C., Karou, T. G., Sanogo, M., Atobla, K. and Niamke, L. N. S. (2014). Prevalence of Salmonella and their antibiotic susceptibility patterns in the District of Abidjan, Côte d'Ivoire. International Journal of Biology Chemistry and Sciences, 5(2), 450-458.

6. Bonny, A. C., Sanogo, M., Karou, A. T. G. and Atobla, K. (2018). Contamination of chicken gizzards by Salmonella spp. : Impact on consumer health in Abidjan, Côte d'ivoire. Journal of Animal \& Plant Sciences, 38(2), 11p. 
7. Bouzidi, N. (2013). L'epidemiologie des infections des élevages de poules pondeuses des régions d'annaba et el-tarf par les salmonelles : Sous-typage moléculaire et Mécanismes de résistance aux antibiotiques des souches isolées. Thèse de Doctorat de l'université Badji Mokhtar, Algérie. 188 p.

8. Cardinale, E., Tall, F., Gueye, E. F., Cisse, M. and Salvat, G. (2004). Risk factors for Salmonella enterica subsp. enterica infection in Senegalese broiler-chicken flocks. Prev. Vet. Med, 63, 151-161.

9. Carli, K. T., Eyigor, A. and Caner, V. (2001). Prevalence of Salmonella serovars in chickens in Turkey. Journal of Food Protection, 64, 1832-1835.

10. Chaslus-Dancla, E. (2003). Les antibiotiques en élevage : état des lieux et problèmes posés. Source : INRA. http: wwwtours.inra.fr urbaseînternet'equipes abr.htm.

11. Diouf, K. C. N. (2006). Surveillance de la résistance aux antibiotiques des souches de Salmonella spp. et Escherichia coli isolées de la viande de poulet de chair au Sénégal. Mémoire de DEA de l'Ecole Inter-Etats des Sciences et Médecine Vétérinaires (E.I.S.M.V), Dakar; Sénégal 60 p.

12. El Allaoui, A., RhaziFilali, F., Ameur, N. and Bouchrif, B. (2017). Contamination des élevages de dinde de chair par Salmonella spp. au Maroc: prévalence, antibiorésistances et facteurs de risque associés. Scientific and Techical Review: International Office ofEpizootics, 36(3), 935-946.

13. Fallah, H. S., Asgharpour, F. Z. N. and Moulana, Z. (2013). Isolation and Détermination of Antibiotic Résistance Patterns in Non typhoid Salmonella spp isolated from chicken. International Journal of Entric Pathogens, 7(1), 5 p.

14. Goburn, B., Grassl, G. A. and F inlay, B. B. (2007). Salmonella, the host and disease: A brief review. Immunology and Cell. Biology(85), 112-118.

15. Gordana, M., Bogdanka, A., Dragica, T., Milena, L. and Brankica, D. (2012). Antibiotic susceptibility of Salmonella spp.: a comparison of two surveys with a 5 years interval. Journal of International Medical Association Bulgaria- Annual Proceeding (Scientifîc Papers), 1S, 216219.

16. ISO-6579-1. (2017). International Standard: microbiology of foodchain - horizontal method for the detection, enumeration and serotyping of Salmonella.

17. Karou, G. T., Bonny, A. C., Ouattara, G. H., Dadie, A. T. and AhonzoNiamke, S. L. (2013). Prevalence of Salmonella and antimicrobial 
résistance of serovars in retail chicken gizzards. International Journal of medical and applied Sciences, 2, 2320-3137.

18. Karraouan, B. A., Fassouane, H., El-Ossmani, N. C. O. and Charafeddine, B. B. (2010). Prévalence et gènes de virulence des Salmonella isolées des viandes hachées crues de dinde à Casablanca (Maroc). Revue de Médecine Vétérinaire, 161(3), 127-132.

19. Myskovâ, P. and Karpîskovâ, R. (2017). Prevalence and Characteristics of Salmonella in Retail Poultry and Pork Meat in the Czech Republic in 2013-2014. Czech Journal of Food Sciences, 35(2), 106-112.

20. Ouattara, N. D., Guessend, N., Gbonon, V., Toe, E., Dadié, T. and Tiécoura, B. (2013). Consommation des Antibiotiques dans la filière Aviaire à Abidjan: Cas de quelques fermes semi-industrielles. European Journal of Scientific Research, 94, 80-85.

21. Piebeng, G. N. K., Tamungang, S. A., Fusingwa, C., Ndukum, J. A., Bayoï, J. R., Gapessie, L. and B., K. (2014). Profils bactériens et fongiques dans les fèces des tisserins villageois (Ploceus cucullatus) dans la ville de Dschang et ses environs (Ouest Cameroun). International Journal of Biological and chemical Sciences, 5(4), 17711783.

22. Rafiullah, A. A., Muhammad, I. A., Inamullah, W., Naimatullah, K., Imtiaz, A. S. and Amin, U. R. (2018). Antimicrobial Résistance of Salmonella Species Isolates from Broiler Birds in District Peshawar. South Asian Journal of Life Sciences, 6(2), 46-53.

23. Traoré, I. (2003). Portage et antibiorésistance des souches de Salmonella isolées des viscères de poulets vendus sur les marchés d'Abobo(Abidjan) Côte d'ivoire, Mémoire de DEA, UFR Sciences et Technologie des Aliments, Université d'Abobo-Adjamé: Abidjan, Côte d'ivoire. 58 p.

24. WHO. (2010). World Health Organization. Antimicrobial susceptibility of Salmonella enterica serovars in a tertiary care hospital in southern India. Indian Journal of Medical Research, 137, 800-802. 